\title{
Niche partitioning among and within sympatric tropical seabirds revealed by stable isotope analysis
}

\author{
Hillary S. Young ${ }^{1, *}$, Douglas J. McCauley ${ }^{1}$, Rodolfo Dirzo ${ }^{1}$, Robert B. Dunbar ${ }^{2}$, \\ Scott A. Shaffer ${ }^{3}$ \\ ${ }^{1}$ Department of Biology and ${ }^{2}$ Environmental Earth System Science, Stanford University, Stanford, California 94305, USA \\ ${ }^{3}$ Department of Biological Sciences, San José State University, San José, California 95192, USA
}

\begin{abstract}
The low productivity and unpredictable nature of resources in tropical waters would appear to make resource partitioning among predators difficult. Yet, stable isotope data from the present study suggest that substantial resource partitioning occurs among tropical seabird communities, both between and within species. In the present study, we compared $\delta^{13} \mathrm{C}$ and $\delta^{15} \mathrm{~N}$ levels among 8 sympatric tropical seabird species. For a subset of these species, we also examined isotopic levels across years, breeding periods, and sexes. When breeding and non-breeding periods were both considered, we found that all species occupied distinct isotopic niches across at least one time period. Resource partitioning by age (within the same year) and year studied (for birds of the same age), within species was observed in all the species we examined. However, niche separation by sex appeared to be relatively uncommon even in sexually dimorphic species. As a group, seabirds were isotopically distinct from other marine predators. There was a strong correlation between both body mass and wing loading ratios and foraging area, as evaluated using $\delta^{13} \mathrm{C}$ levels. Cumulatively, the isotopic patterns observed are consistent with diet-based surveys of resource partitioning during the breeding period. Importantly, these data provide additional evidence to suggest that substantial niche partitioning among tropical seabird species persists even during non-breeding periods in open ocean environments, when direct diet-based surveys are difficult to conduct.
\end{abstract}

KEY WORDS: Resource partitioning $\cdot$ Foraging ecology $\cdot \delta^{13} \mathrm{C} \cdot \delta^{15} \mathrm{~N} \cdot$ Marine predators

Resale or republication not permitted without written consent of the publisher

\section{INTRODUCTION}

Tropical open ocean environments generally have lower productivity and lower structural complexity, and thus patchier and more unpredictable distributions of prey than temperate oceans (Longhurst \& Pauly 1987, Ballance et al. 1997). High trophic level marine predators thus face many challenges locating prey and have likely evolved behavioral and morphological adaptations that facilitate energetically efficient travel and foraging behavior (Bertrand et al. 2002, Weimerskirch et al. 2004). Despite these constraints, diverse communities of marine predators, particularly seabirds, exist, leading to questions about the degree, nature, and mechanisms of resource partitioning in these relatively unpredictable and nutrient-limited environments.
Resource partitioning in oceanic environments has been well documented for temperate and polar seabird species (Ainley et al. 1992, 1994), but remains an area of much inquiry for tropical species, particularly in open ocean environments (Harrison \& Seki 1987, Catry et al. 2009). Tropical seabird diets are more diverse than their temperate and polar counterparts, and there can be a high degree of overlap in diets and foraging areas (Ballance et al. 1997, Catry et al. 2009). Most tropical species are also limited to foraging within the first several meters of the sea surface, and they often rely on subsurface predators to drive food to the surface, further increasing the patchy nature of food resources (Ballance et al. 1997). These observations have led to questions about the degree to which tropical seabird species are able to partition resources. 
While there have been several comprehensive extensive studies of the diets of seabird communities (using stomach contents) in tropical environments, these have generally been constrained to the breeding season (Ashmole \& Ashmole 1967, Harrison et al. 1983, Catry et al. 2009). The only study to comprehensively explore the diet contents of non-breeding and breeding tropical seabird communities found higher degrees of resource partitioning than found in a similar study of polar seabirds (Spear et al. 2007). In that study, Spear et al. (2007) found evidence of partitioning by species, sex, age, foraging strategy, and body size. There was even a high degree of prey separation among species foraging in the same flocks. However, Spear et al. (2007) found incomplete partitioning among species, and several of the species were statistically indistinguishable from one another.

Despite the many strengths of at-sea surveys of seabird diet contents and the detail of data resolution achieved, this methodology has some inherent limitations for answering questions about resource partitioning. Since seabirds are typically sampled lethally, the stomach contents from each animal contribute only a single data point in space and time, and it is thus not possible to examine changes in individual foraging behavior across space and time. Also, it is not possible to link foraging behavior to reproductive status using these methods, although it is likely that reproductive status influences foraging behavior (Schaffer et al. 2003). Additionally, collections across long time periods may compare foraging across heterogeneous time periods.

Stable isotope analysis (SIA) has been shown to provide an excellent complementary tool for understanding resource partitioning, both spatially and by trophic level (Bearhop et al. 2002). Stable isotopes of carbon and nitrogen in seabird tissue are derived from the isotopic values of their prey and give insight into the origin and type of prey consumed (although they do not provide detailed information on prey identity or capture method, which is available from dietary analysis or direct observation). Stable carbon isotopes show evidence of an increasing enrichment in inshore as compared to offshore feeding animals in both tropical and temperate areas (Cherel et al. 2008). For tropical surface-feeding seabirds, benthic to surface gradients in carbon isotopes are likely not directly relevant. However, in comparing seabirds to other marine predators, the enriched carbon values found in benthic habitats are also an important consideration. Stable nitrogen isotopes increase in a predictable matter with each trophic step, and thus indicate trophic position of a consumer (Vanderklift \& Ponsard 2003). There do not seem to be strong species-specific fractionation rates among fish-eating seabirds (Cherel et al. 2005a), so differences across species within a system are likely due to diet differences. Comparisons across systems must be undertaken with more caution; clear and strong gradients across latitudes exist both for carbon ( $>10 \%$, with less negative values in the tropics) and for nitrogen $(>6 \%$, with lower values in the tropics; Graham et al. 2010). Since different tissues (e.g. feathers, blood) integrate these stable isotopes over different periods of time, a single bird can provide integrated information on diet over a period of time ranging from days to years, depending on the tissues analyzed (Dalerum \& Angerbjörn 2005).

SIA has yielded important insights into subtle changes in seabird foraging ecology based on reproductive stage (e.g. Awkerman et al. 2007), age (e.g. Forero et al. 2002), colony location (e.g. Jaquemet et al. 2008), sex (e.g. Bearhop et al. 2006), migratory patterns (e.g. Cherel et al. 2000), as well as other factors (e.g. Cherel et al. 2005b, Phillips et al. 2009). Since SIA is a robust, non-lethal method to resolve spatial and trophic separation among species, it is a useful tool to examine resource partitioning among seabirds in tropical environments, particularly for those species that are too small for current electronic tracking methods. A few studies have used SIA to examine resource partitioning on a community scale in the tropics (Catry et al. 2008, Cherel et al. 2008, Kojadinovic et al. 2008). Those studies, all conducted in the Southern Indian Ocean, showed relatively small variation in stable isotopes across species $(<2 \%$ o variation across species, within a tissue type). However, they reached different conclusions, both in the degree of resource partitioning and the usefulness of isotopes as a tool for identifying foraging patterns in the tropics.

Our study site, Palmyra Atoll (equatorial Pacific), is quite different from the other tropical study sites where SIA has been conducted, in that Palmyra is far (1000s of km) from any continental shelf and has lower heterogeneity in oceanic conditions (productivity, sea surface temperature, bathymetry; Weimerskirch et al. 2005, Young et al. 2010). This site may thus more generally typify the open ocean conditions experienced by many tropical seabirds, particularly during the nonbreeding period. It also has a remarkably intact surrounding marine community, with naturally high biomass of high trophic level predators (Stevenson et al. 2007). This, combined with the high number of cooccurring nesting species examined in the present study, creates an ideal situation to examine niche partitioning within and among these marine predators.

The aims of the present study were to (1) determine if there is isotopic evidence for significant resource partitioning among tropical seabird species living in an open and relatively intact ocean environment; (2) compare patterns of isotopic partitioning in blood and 
feathers to evaluate differences in partitioning among species in breeding (blood) and non-breeding (feather) periods; (3) examine isotopic evidence of resource partitioning within species across different age classes and sexes; and (4) compare seabird resource use to that of other marine predators (predatory fish and invertebrates), with whom seabirds must also compete for resources. We compared our stable isotope results to data from conventional stomach content analyses, at-sea surveys, and known natural history. These comparisons included multiple congeneric species, and species with similar foraging strategies, where finescale niche partitioning might be particularly important for mitigating competitive interactions.

\section{MATERIALS AND METHODS}

Study site and species. Our research was conducted at Palmyra Atoll National Wildlife Refuge $\left(5.867^{\circ} \mathrm{N}\right.$, $\left.162.067^{\circ} \mathrm{W}\right)$. Palmyra Atoll is a tropical atoll located in the Line Island chain in the central Pacific Ocean. It is situated on the boundary of the intertropical convergence zone (Longhurst \& Pauly 1987). The surrounding waters are generally low in productivity, warm, and deep (Young et al. 2010). The seabird community at Palmyra consists of 10 breeding species in 2 orders: (1) Charadriiformes: sooty terns Sterna fuscata ( 125 000220000 pairs), white terns Gygis alba ( 200 pairs), brown noddies Anous stolidus ( 500 pairs), and black noddies $A$. minutus ( 1000 pairs); and (2) Pelecaniformes: great frigatebird Fregata minor ( 250 pairs), red-footed boobies Sula sula ( 2500 pairs), brown booby S. leucogaster ( 400 pairs), masked booby $S$. dactylatra ( 35 pairs), red-tailed tropicbirds Phaethon rubricauda ( 150 pairs), and white-tailed tropicbirds $P$. lepturus ( 10 pairs) (Fefer 1987, H. S. Young unpubl. data). At Palmyra these birds breed asynchronously throughout the year.

Sample collection. We collected feather samples from 9 of the 10 species that breed at the atoll (all except white-tailed tropicbirds; Table 1). Samples were collected from breeding adults (either incubating or chick rearing), with the exception of samples from white terns, where reproductive status was unknown. All samples were collected in July 2009, except for sooty terns, which did not breed in summer 2009; for this species, we thus used feathers collected in July 2008. For red-footed boobies, additional samples were collected from breeding adults in 2 previous years (July 2007, $\mathrm{n}=15$; and July $2008, \mathrm{n}=25$ ) for interannual comparisons. To examine resource differentiation between parents and offspring (e.g. via selective feeding), for 5 species we also analyzed feathers collected from unfledged chicks in 2009 (black noddy, $\mathrm{n}=8$; red-footed booby, $\mathrm{n}=10$; redtailed tropicbird, $\mathrm{n}=15$; brown booby, $\mathrm{n}=10$ ). For redfooted boobies only, we also compared immature birds (fledged, but not yet in adult plumage; $\mathrm{n}=10$ ) to adults and chicks. Since feathers of adults are formed in the non-breeding period, while those of chicks and juveniles are formed during the breeding period, differences observed may also be due to foraging differences across these time periods. Four sexually dimorphic species were examined for sexual differences in resource partitioning (red-footed booby, $\mathrm{n}=6$ per sex; brown booby, $\mathrm{n}=8$ per sex; masked booby, $\mathrm{n}=$ 7 per sex; great frigatebird, $\mathrm{n}=7$ female and 11 male). Birds were sexed using voice, plumage, and/or molecular sexing methods (Young et al. 2010).

For feather samples we used unabraded underwing contour feathers (Jaeger et al. 2009). Blood was also collected from a brachial vessel from a subset of the individuals that were sampled for feathers. Body mass and wing loading for all species were estimated from Hertel \& Ballance (1999) and Spear \& Ainley (1997).

Table 1. Stable isotope ratios of carbon and nitrogen and mass ratio of $\mathrm{C}: \mathrm{N}$ in feathers and blood of seabirds, and muscle tissue of other pelagic predators. For seabirds, superscript letters denote significant differences between species in post hoc analyses; values not sharing the same letter are significantly different (comparisons are within tissue type). Brown noddies were not considered in post hoc comparisons due to small sample size. Values are mean $\pm \mathrm{SD}$

\begin{tabular}{|lrccc|}
\hline Species & $\mathrm{n}$ & $\delta^{15} \mathrm{~N}$ & $\delta^{13} \mathrm{C}$ & $\mathrm{C}: \mathrm{N}$ \\
\hline Feathers: seabirds & & & & \\
Black noddy & 18 & $14.79 \pm 1.90^{\mathrm{AB}}$ & $-16.87 \pm 0.32^{\mathrm{A}}$ & $3.34 \pm 0.07$ \\
Brown noddy & 3 & $16.35 \pm 0.31$ & $-16.12 \pm 0.25$ & $3.37 \pm 0.01$ \\
Sooty tern & 21 & $14.7 \pm 2.80^{\mathrm{AB}}$ & $-16.30 \pm 0.28^{\mathrm{B}}$ & $3.23 \pm 0.03$ \\
White tern & 20 & $16.20 \pm 1.69^{\mathrm{A}}$ & $-15.91 \pm 0.29^{\mathrm{C}}$ & $3.16 \pm 0.04$ \\
Brown booby & 21 & $14.08 \pm 1.39^{\mathrm{B}}$ & $-15.43 \pm 0.31^{\mathrm{D}, \mathrm{E}}$ & $3.18 \pm 0.03$ \\
Masked booby & 15 & $14.17 \pm 0.98^{\mathrm{B}}$ & $-15.22 \pm 0.24^{\mathrm{E}}$ & $3.18 \pm 0.03$ \\
Red-footed booby & 12 & $13.85 \pm 1.25^{\mathrm{B}}$ & $-15.73 \pm 0.34^{\mathrm{C}, \mathrm{D}}$ & $3.22 \pm 0.03$ \\
Great frigatebird & 19 & $16.03 \pm 1.09^{\mathrm{A}}$ & $-16.26 \pm 0.20^{\mathrm{B}}$ & $3.27 \pm 0.03$ \\
Red-tailed tropicbird & 26 & $15.35 \pm 1.70^{\mathrm{AB}}$ & $-15.61 \pm 0.27^{\mathrm{D}}$ & $3.14 \pm 0.03$ \\
Blood: seabirds & & & & \\
Sooty tern & 17 & $14.29 \pm 1.52^{\mathrm{A}}$ & $-18.02 \pm 0.13^{\mathrm{A}}$ & $3.33 \pm 0.11$ \\
Brown booby & 10 & $15.67 \pm 0.72^{\mathrm{B}}$ & $-17.20 \pm 0.12^{\mathrm{B}}$ & $3.30 \pm 0.03$ \\
Masked booby & 9 & $14.21 \pm 0.61^{\mathrm{A}}$ & $-17.15 \pm 0.18^{\mathrm{C}}$ & $3.40 \pm 0.06$ \\
Red-footed booby & 11 & $13.79 \pm 0.44^{\mathrm{A}}$ & $-17.42 \pm 0.09^{\mathrm{D}}$ & $3.31 \pm 0.04$ \\
Great frigatebird & 5 & $16.07 \pm 0.72^{\mathrm{B}}$ & $-17.20 \pm 0.12^{\mathrm{C}, \mathrm{D}}$ & $3.41 \pm 0.03$ \\
Muscle: other predators & & & & \\
Acanthocybium solandri & 15 & $14.53 \pm 3.15$ & $-16.21 \pm 1.24$ & $3.15 \pm 0.06$ \\
Thunnus albacores & 25 & $14.63 \pm 0.96$ & $-16.68 \pm 0.36$ & $3.16 \pm 0.15$ \\
Sthenoteuthis spp. & 11 & $12.82 \pm 1.02$ & $-17.62 \pm 0.27$ & $3.18 \pm 0.05$ \\
& & & & \\
\hline
\end{tabular}


Field metabolic rate $\left(\mathrm{kJ} \mathrm{d}^{-1}\right)$ was estimated from allometric equations derived for Pelicaniformes and Charadriformes (Shaffer in press).

To compare seabirds to other pelagic predators, muscle tissue from pelagic fish predators, wahoo Acanthocybium solandri $(\mathrm{n}=15)$ and yellowfin tuna Thunnus albacares $(\mathrm{n}=25)$, was collected from animals captured from within $3 \mathrm{~km}$ of the reef immediately surrounding the atoll during July to August of multiple years (2007 to 2009). Flying squid Sthenoteuthis spp. $(\mathrm{n}=11)$ were captured approximately $700 \mathrm{~km}$ from the atoll (May 2007). Comparisons among seabirds and other marine predators only included the 5 seabird species for which blood data were available (as feathers are likely not directly comparable to muscle tissue; Hobson \& Clark 1992).

Sample preparation and isotope analyses. Feathers were washed in deionised water, dried at $60^{\circ} \mathrm{C}$ for storage, and subsequently cut into fine pieces for analysis. Blood and muscle samples (from seabirds and other marine predators) were all preserved frozen at $-80^{\circ} \mathrm{C}$. They were then freeze dried and ground to a fine powder. We did not extract lipid from any tissues, as C:N ratios were always less than 4.0 , and usually less than 3.5 , suggesting lipid levels were low across all samples (Post et al. 2007).

Stable isotopic ratios of $\mathrm{C}$ and $\mathrm{N}$ were analyzed at the Stanford Stable Isotope Biogeochemistry Laboratory (SIBL) using a Thermo Finnigan Delta-Plus XP IRMS coupled to a Carlo Erba NA 1500 Series 2 elemental analyzer. Replicate laboratory standards of graphite NIST RM 8541 (USGS 24), and ammonium sulfate NIST RM 8547 (IAEA N1) internal to each run showed an analytical error of $<0.2 \%$ for both $\mathrm{C}$ and $\mathrm{N}$.

Isotope interpretations. The interpretation of carbon isotope values presented in this paper is based on the assumption that the established inshore to offshore gradient of $\delta^{13} \mathrm{C}$ (Cherel \& Hobson 2007, Graham 2009) is likely the primary driver for changes in stable carbon isotopes of the seabirds measured in the present study. Although Palmyra Atoll has a limited reef area, a $\delta^{13} \mathrm{C}$ gradient exists between reef fish and more pelagic fish (D. J. McCauley et al. unpubl. data). Changes in carbon isotopes due to trophic level differentiation are presumed to be generally small in seabirds, and given the limited range of $\delta^{15} \mathrm{~N}$ observed in the present study, trophic variation is not likely to be an important explanatory factor of $\delta^{13} \mathrm{C}$ here (Kelly 2000). Variation in $\delta^{15} \mathrm{~N}$ within a tissue type is likely primarily due to differences in trophic position.

We further assumed that there is no size or age specific fractionation rates of either carbon $(\Delta \mathrm{C})$ or nitrogen $(\Delta \mathrm{N})$ isotopes within seabirds (Cherel et al. 2005a). We did not directly compare $\delta^{15} \mathrm{~N}$ or $\delta^{13} \mathrm{C}$ across tissue types, given different isotopic signatures and fraction- ation rates of these tissues (Cherel et al. 2005a). The period of isotopic integration in blood was assumed to be days to weeks, such that blood taken from a breeding bird is assumed to give diet information on the breeding period (Hobson \& Clark 1992). Since feathers are usually molted after reproduction, and are inert thereafter, feather samples were assumed to represent the composition of the diet during the non-breeding period (Bearhop et al. 2002).

Statistical analyses. To examine differences in resource partitioning among species, we used multivariate analysis of variance (MANOVA), with subsequent univariate ANOVA tests of differences in $\delta^{13} \mathrm{C}$ and $\delta^{15} \mathrm{~N}$, with post hoc Tukey HSD analyses. Due to the small sample size of brown noddies, they were not considered in post hoc analyses. Statistical analyses were performed in JMP 8 (SAS Institute). When necessary to meet assumptions of normality and homoscedasticity, data were transformed using Box-Cox transformation. All figures and tables depict untransformed data. All data are reported as untransformed means $\pm 1 \mathrm{SD}$.

\section{RESULTS}

\section{Resource partitioning among species in breeding and non-breeding periods}

The 9 species of adult seabirds showed significant overall isotopic segregation in feather samples (MANOVA, Wilks' lambda, $F_{16,288}=12.49, \mathrm{p}<0.0001$; Fig. 1A). Univariate tests of feathers across species also showed significant differences in both $\delta^{13} \mathrm{C}$ (ANOVA, $\left.F_{7,145}=30.41, \mathrm{p}<0.0001\right)$ and $\delta^{15} \mathrm{~N}$ (ANOVA, $F_{7,145}=$ $5.20, \mathrm{p}<0.0001)$. Results from post hoc Tukey pairwise comparisons showed significant differences in $\delta^{13} \mathrm{C}$ among most species, although not between every species pair (Table 1). For $\delta^{15} \mathrm{~N}$, the 3 booby species were all significantly different from the white tern and the great frigatebird; there were no other significant differences (Table 1).

The 5 species sampled for blood also showed significant overall isotopic segregation (MANOVA, Wilks' lambda, $F_{8,90}=36.63, \mathrm{p}<0.0001$; Fig. 1B). Univariate tests showed significant differences both for $\delta^{13} \mathrm{C}$ (ANOVA, $\left.F_{4,46}=129.10, \mathrm{p}<0.0001\right)$ and for $\delta^{15} \mathrm{~N}$ (ANOVA, $F_{4,46}=30.41, \mathrm{p}<0.0001$ ). In post hoc analyses, all seabird species had distinct values for $\delta^{13} C_{\text {, }}$ except great frigatebirds, which were indistinguishable from either masked or red-footed boobies (Table 1). For $\delta^{15} \mathrm{~N}$, great frigatebirds and brown boobies were statistically different from the other 3 species (Table 1).

All seabirds differed from one another in at least 1 of the 2 stable isotopes measured in blood or feathers. The total range spanned in mean values among spe- 

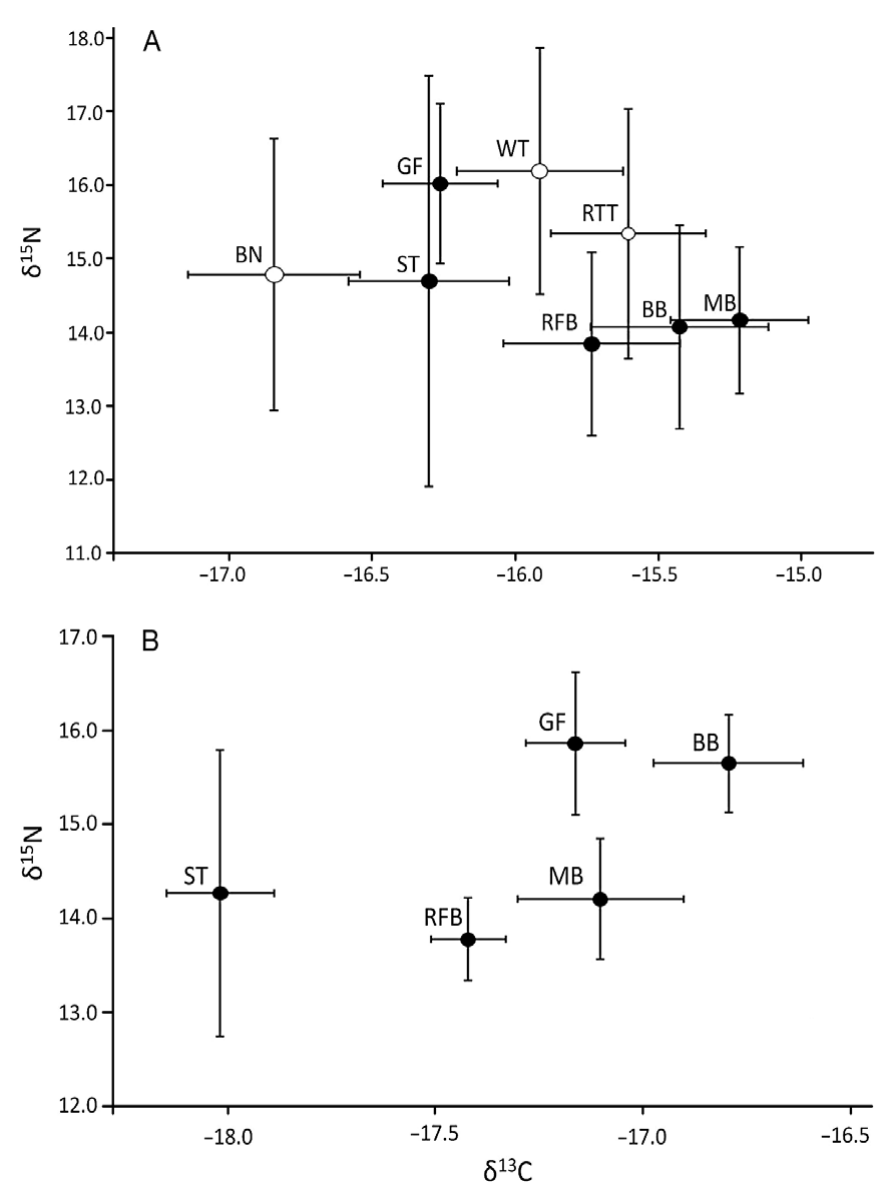

Fig. 1. Stable carbon and nitrogen isotope values (mean \pm SD) from 8 seabird species from Palmyra Atoll. (A) Values from feathers; solid black symbols denote those species for which isotope values of blood are also presented in panel $B_{\text {; }}$ (B) blood values only. BB: brown booby; BN: black noddy; $\mathrm{MB}$ : masked booby; GF: great frigatebird, RFB: red-footed booby; RTT: red-tailed tropicbird; ST: sooty tern; WT: white tern

cies was $1.2 \%$ (in feathers) and 1.8\% (in blood) for $\delta^{13} \mathrm{C}$, and $2.5 \%$ (in feathers) and $2.3 \%$ (in blood) for $\delta^{15} \mathrm{~N}$. The pattern of trophic partitioning among species changed somewhat between blood and feathers, with great frigatebirds having a relatively lower $\delta^{13} \mathrm{C}$ in feathers compared to blood, and brown boobies a relatively higher $\delta^{13} \mathrm{C}$ in feathers compared to blood.

Comparison of mean $\delta^{13} \mathrm{C}$ by mean body mass per species yielded a significant positive relationship $\left(\mathrm{R}^{2}=\right.$ 0.67, $\mathrm{p}<0.01$ ), with higher $\delta^{13} \mathrm{C}$ enrichment in larger birds (Fig. 2). The relationship improved further when $\delta^{13} \mathrm{C}$ was compared to wing loading $\left(\mathrm{R}^{2}=0.82\right.$, $\mathrm{p}<$ 0.01 ), where birds with lower wing loading were more enriched with $\delta^{13} \mathrm{C}$. There was also a strong positive relationship between estimated field metabolic rate and $\delta^{13} \mathrm{C}\left(\mathrm{R}^{2}=0.74, \mathrm{p}<0.01\right)$. There were no significant relationships between any of the above variables and $\delta^{15} \mathrm{~N}$ values.

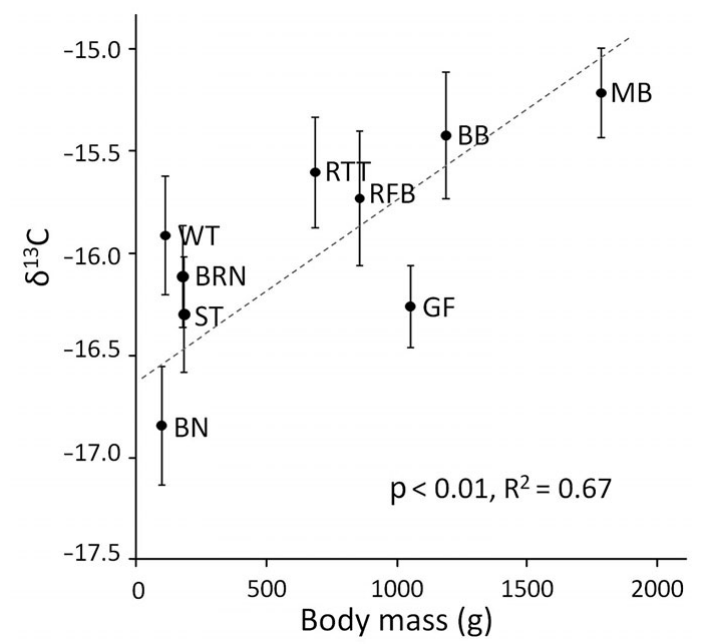

Fig. 2. Stable isotope values of carbon compared to body mass. Species codes are the same as in Fig. 1, with the addition of BRN: brown noddy

\section{Resource partitioning within species}

Of the 5 species for which adult and chick feathers were compared, 4 showed significantly higher $\delta^{15} \mathrm{~N}$ values in chicks than in adults (black noddy, $t=2.47$, $\mathrm{p}=0.02$; red-footed booby $t=2.92, \mathrm{p}=0.01$; red-tailed tropicbird, $t=5.63, \mathrm{p}<0.0001$; brown booby $t=2.71$, $\mathrm{p}=0.01$ ). For red-footed boobies, when juvenile birds were also considered there were similarly significant effects (MANOVA, Wilks' lambda, $F_{4,44}=3.21, \mathrm{p}=$ $0.02)$, with chicks having slightly higher $\delta^{15} \mathrm{~N}$ values $\left(F_{2,23}=5.49, \mathrm{p}=0.01\right)$ than either adult or juvenile birds (Fig. 3). Great frigatebirds were the only species to show a marginally significant increase in $\delta^{15} \mathrm{~N}(t=1.82$, $\mathrm{p}=0.08$; Fig. 4). Only 1 species, red-tailed tropicbirds, showed significant differences in $\delta^{13} \mathrm{C}$ by age, with adult birds having lower $\delta^{13} \mathrm{C}$ than chicks $(t=5.63$, $\mathrm{p}<$ 0.0001).

Among the 4 species analyzed for effects of sex on isotopes, significant differences were found for only 1 species, the brown booby. Male brown boobies had lower $\delta^{13} \mathrm{C}(t=4.23, \mathrm{p}<0.001)$ and lower $\delta^{15} \mathrm{~N}(t=2.40$, $\mathrm{p}=0.03$ ) than females.

There was a slight but significant interannual difference in $\delta^{13} \mathrm{C}$ of feathers for breeding adult red-footed boobies (ANOVA, $F_{4,126}=4.10, \mathrm{p}<0.01$ ), where boobies in 2007 had slightly higher $\delta^{13} \mathrm{C}$ values than birds in either 2008 or 2009 (ANOVA, $F_{2,50}=3.61, \mathrm{p}=0.03$; Fig. 3). No such trend was detected in $\delta^{15} \mathrm{~N}$.

\section{Comparisons of seabirds to other marine predators}

As a group, seabirds were isotopically distinct from other large pelagic predators (MANOVA, Wilks' 


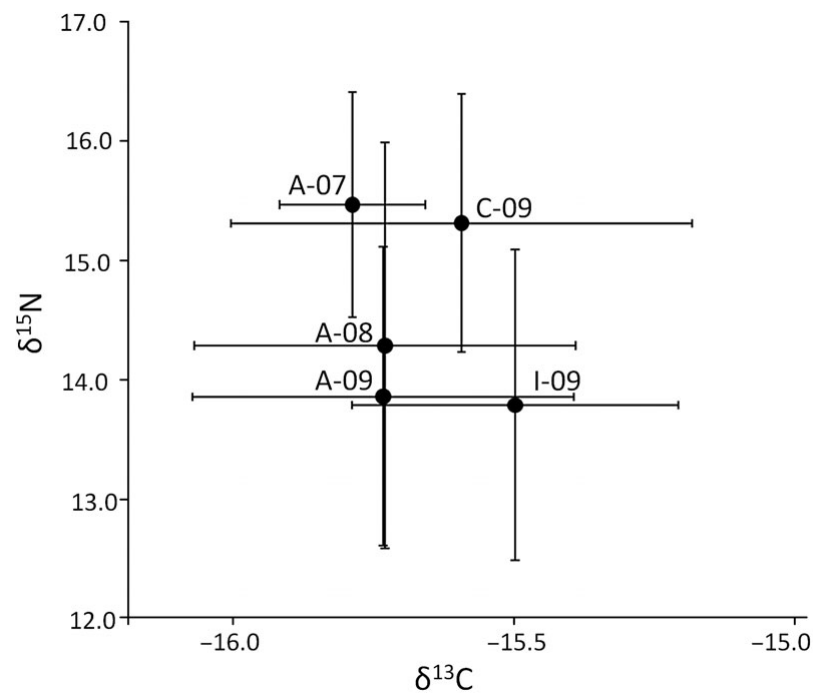

Fig. 3. Sula sula. Comparison of stable carbon and nitrogen isotope values for feathers from red-footed boobies across multiple years and age classes. The first letter indicates age class (A: adult; I: immature; C: chick), and the number indicates the year in which samples were collected (2007, 2008, or 2009)

Lambda, $F_{6,298}=23.26, \mathrm{p}<0.0001$; Fig. 5) with large predatory fish (wahoo, yellowfin tuna) having higher $\delta^{13} \mathrm{C}$ than seabirds or the large predatory Sthenoteuthis squid $\left(F_{6,149}=64.93, \mathrm{p}<0.0001\right)$. Sthenoteuthis spp. had lower $\delta^{15} \mathrm{~N}$ than seabirds or large predatory fish $\left(F_{6,149}=15.87, \mathrm{p}<0.0001\right)$. On a species by species basis there was some overlap, with brown boobies being statistically indistinguishable from yellowfin tuna, and red-footed boobies being statistically indistinguishable from Sthenoteuthis spp. (Fig. 5).

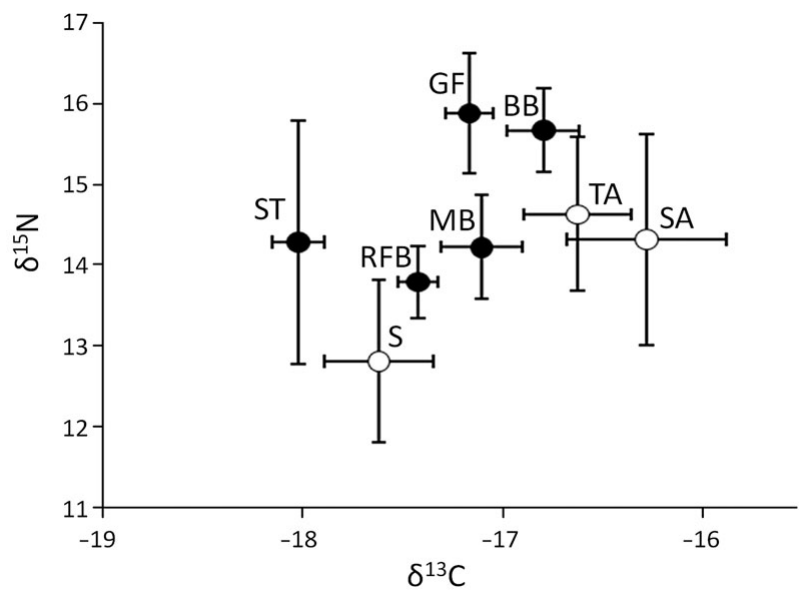

Fig. 5. Stable carbon and nitrogen isotope values of seabirds (filled symbols), and pelagic fish and invertebrate predators around Palmyra Atoll (unfilled symbols). AS: Acanthocybium solandri (wahoo); TA: Thunnus albacares (yellowfin tuna); S: Sthenoteuthis spp. (flying squid). Seabird codes are the same as in Fig. 1

\section{DISCUSSION}

There were significant differences in either carbon or nitrogen isotopes among all species examined in either breeding or non-breeding periods. This suggests that all the sympatric seabird species examined may be occupying distinct ecological niches, when both breeding and non-breeding periods are considered. The degree of partitioning observed in the nonbreeding period was more complete than the partitioning detailed by at-sea surveys and diet analyses (Surman \& Wooller 2003, Spear et al. 2007).

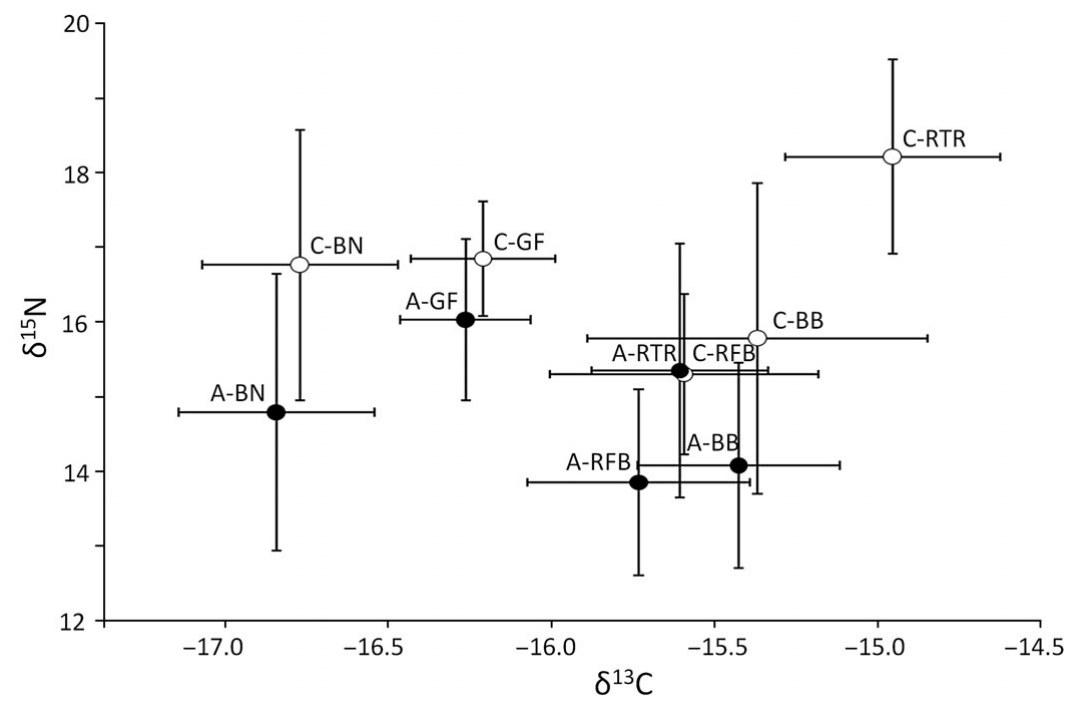

Fig. 4. Stable carbon and nitrogen isotope values of feathers compared across age classes for multiple seabird species. Adults (A) are indicated by unfilled symbols and chicks (C) are indicated by filled symbols. Different species are indicated by codes (as in Fig. 1)

\section{Resource partitioning by species in the non-breeding period}

The patterns observed in $\delta^{13} \mathrm{C}$ in the nonbreeding period (feathers) were generally consistent with data from tracking and at-sea surveys. Sooty terns and great frigatebirds have the most pelagic signal, followed sequentially by white terns, red-footed boobies, red-tailed tropicbirds, brown boobies and masked boobies (Ballance et al. 1997, Jaquemet et al. 2005). One surprising result based on carbon isotope levels was the highly pelagic signal of black noddies (i.e. values were more negative than that of any other species). This species is generally considered to be an opportunistic nearshore feeder that is often seen foraging near jacks and within lagoons (Ashmole 1968, Seki \& Harrison 1989). Yet values of 
carbon isotope levels in lagoon waters at Palmyra are particularly elevated, and black noddy isotope levels do not resemble those of reef jacks at Palmyra (D. J. McCauley et al. unpubl. data). Studies of procellariiforms have found that relatively negative $\delta^{13} \mathrm{C}$ values can derive from the assimilation of carbon from dietary lipids (Thompson et al. 2000). It is possible that black noddies have differential abilities to incorporate dietary lipids than other species studied, although this seems unlikely given the lack of similarly negative $\delta^{13} \mathrm{C}$ in brown noddies. Given the small total range of $\delta^{13} \mathrm{C}$ observed, controlled measurements of species-specific fractionation rates would be helpful to confirm that species-specific fractionation rates do not drive these patterns (Becker et al. 2007). Likewise, while $\delta^{13} \mathrm{C}$ maps available for the equatorial Pacific Ocean do not suggest high variation in $\delta^{13} \mathrm{C}$ around this region, that is based on limited sampling near Palmyra (Graham 2009); thus, better finescale isotopic sampling of oceans in this region would improve the accuracy of our interpretations.

Species-level changes in $\delta^{13} \mathrm{C}$ were highly correlated to body mass, with smaller birds exhibiting a more pelagic signature than larger species. Since body mass co-varies with wing loading and with metabolic rate, it is possible that either or both of these variables may partially drive these patterns. However, since laboratory manipulations of metabolic rate in birds via exercise and cold show no effect of metabolic rate on $\Delta \mathrm{C}$, it seems unlikely that differential metabolic rates drive these patterns (Bauchinger et al. 2010).

Nitrogen isotopes from non-breeding periods (feathers) showed that great frigatebirds had elevated $\delta^{15} \mathrm{~N}$ levels over many species, including all the boobies (consistent with Cherel et al. 2008). When at the colony, these birds also often consume chicks of various smaller species and steal partially regurgitated food from other birds, potentially explaining this variation (Schreiber \& Hensley 1976). As found in the Seychelles (Catry et al. 2008), white terns also showed high $\delta^{15} \mathrm{~N}$ levels. While Catry et al. (2008) suggested that this might be reason to discount results of $\delta^{15} \mathrm{~N}$, the consistency across studies perhaps merits further consideration for biologically valid explanations. It is possible that these high levels may be due to the large portion of its diet (>40\%) composed of small, predatory Scombridae (Euthynnus sp.; Spear et al. 2007). This predatory species might be higher in $\delta^{15} \mathrm{~N}$ than flyingfish and squid, which dominate the diet of several other species. Direct measurements of $\delta^{15} \mathrm{~N}$ of these prey would be necessary to resolve this result. The 3 booby species, which feed primarily on flyingfish and squid (Schreiber \& Hensley 1976, Spear et al. 2007 ) showed particularly low $\delta^{15} \mathrm{~N}$ values. Controlled studies of species-specific fractionation patterns would help clarify if physiological factors or trophic differences are influencing $\delta^{15} \mathrm{~N}$ patterns (Becker et al. 2007).

\section{Resource partitioning by species in the breeding period}

Examination of blood samples, representing the breeding interval, also showed distinct niches for each of the species examined. There were small changes in foraging areas in non-breeding as opposed to breeding periods, with great frigatebirds and brown boobies appearing comparatively less pelagic than during the non-breeding interval. For the 2 species for which tracking data were available at Palmyra (red-footed and masked booby), the $\delta^{13} \mathrm{C}$ results were highly consistent with tracking results (with red-footed boobies foraging slightly farther off shore than masked boobies during the breeding period), even though the differences in foraging distances were not extremely large (Young et al. 2010).

The relative positions of $\delta^{13} \mathrm{C}$ and $\delta^{15} \mathrm{~N}$ in both breeding and non-breeding periods observed at Palmyra were highly consistent with those observed on Europa Island and in the Seychelles (Catry et al. 2008, Cherel et al. 2008), suggesting that niche partitioning is consistent in very different parts of the species' ranges. The absolute values of $\delta^{13} \mathrm{C}$ were also consistent in both studies in the non-breeding interval, but slightly depleted at Palmyra during the breeding interval, perhaps due to the more oceanic location of Palmyra itself, as open ocean conditions likely lead to lower $\delta^{13} \mathrm{C}$ values (Graham et al. 2010). In contrast, absolute values of $\delta^{15} \mathrm{~N}$ observed at Palmyra were greatly elevated (by about $2 \%$ ) over those obtained at Europa in both breeding and non-breeding periods. This suggests either a higher baseline of nitrogen at Palmyra than at Europa, or a higher overall trophic position of birds at Palmyra. Similar results were seen in a comparison of the Seychelles to the Mozambique Channel (Jaquemet et al. 2008). This is consistent with latitudinal variations of $\delta^{15} \mathrm{~N}$ in isotopic cartography, suggesting that while it is possible to compare relative $\delta^{15} \mathrm{~N}$ positions across studies, to compare absolute values of $\delta^{15} \mathrm{~N}$, good knowledge of baseline $\delta^{15} \mathrm{~N}$ is needed (Graham et al. 2010).

\section{Partitioning within species}

A comparison of feathers from chicks and adults showed elevated levels of $\delta^{15} \mathrm{~N}$ in chicks across all 5 species examined. This differed from the pattern seen for great frigatebirds on Europa Island, but is consistent with results for sooty terns at the same site (Cherel et al. 2008). This could reflect a shift to higher trophic level prey items during the breeding period (i.e. kleptoparasitism by frigatebirds), selective feeding of food items to young, age specific fractionation, or some effect of regurgitation of food. Other studies have shown differential provisioning of chicks with higher 
quality food, or different trophic level food sources (Hodum \& Hobson 2000, Cherel et al. 2008). While seabird studies have not documented changes in $\Delta \mathrm{N}$ with age, this has been seen in other taxa and could be a viable explanation (Roth \& Hobson 2000). Even without different $\Delta \mathrm{N}$, by feeding on partially digested food, they may be incorporating ${ }^{15} \mathrm{~N}$ from their parents' bodies during the regurgitation process, thus explaining higher $\delta^{15} \mathrm{~N}$ values. Direct comparison of adult and chick blood and diets (not taken here) would help resolve this. The lack of any shift in $\delta^{13} \mathrm{C}$ from adults to chicks was unexpected given that breeding places constraints on seabird foraging distances, but is consistent with the lack of change seen in Seychelles (Catry et al. 2008).

We saw limited evidence of resource partitioning by sex. All 4 species that we examined for sexual partitioning of resources exhibited reverse sexual dimorphism. Of these, we saw differences in $\delta^{15} \mathrm{~N}$ and $\delta^{13} \mathrm{C}$ in only 1 species, the brown booby. The larger females showed higher $\delta^{15} \mathrm{~N}$ and $\delta^{13} \mathrm{C}$, indicating that female brown boobies had a higher trophic level and less pelagic food sources. This is consistent with other evidence of niche partitioning by sex in brown boobies (Weimerskirch et al. 2009b). Likewise, the lack of resource partitioning by sex in red-footed and masked boobies is also consistent with other studies (Weimerskirch et al. 2009a, Young et al. 2010). However, sex differences have been observed in red-footed boobies in other locations (Weimerskirch et al. 2006).

In the 1 species for which we compared data across multiple years, we saw small but significant differences in $\delta^{15} \mathrm{~N}$ for 1 of the 3 years. This may point to small variability in food sources across time even in tropical resources. While it is not always possible to gather samples from all species simultaneously, this suggests caution is needed in interpreting isotopic data from seabirds gathered in different years as evidence of niche partitioning.

\section{Comparisons to other predators}

We saw clear distinctions among seabirds and other marine predators. There was relatively little overlap between pelagic predators and seabirds on a species by species basis. The primary differences in seabirds and predatory fish was the lower $\delta^{13} \mathrm{C}$ of seabirds. This difference may reflect the integration of food from the deep scattering layer and reef (both of which would have higher $\delta^{13} \mathrm{C}$ signatures) into the diets of these fish. This is consistent with other studies reporting that pelagic feeding seabirds have relatively low $\delta^{13} \mathrm{C}$ values compared to benthic feeding species (Thompson et al. 2000). Although bird and fish predators often forage together, studies of tropical seabird and other predator diets have shown substantial variation among species (Catry et al. 2009). For Sthenoteuthis spp., the extremely offshore foraging patterns may explain the more negative values in $\delta^{13} \mathrm{C}$ observed, and thus the lack of differentiation from seabirds. The difference in $\delta^{15} \mathrm{~N}$ between Sthenoteuthis spp. and seabirds may reflect the lower trophic level diet observed in Sthenoteuthis spp. (Shchetinnikov 1992).

\section{CONCLUSIONS}

In general, our study supports the idea that there is significant niche partitioning among tropical seabirds even during non-breeding periods, when many species are utilizing similar open ocean environments. There is overlap in resource use among species during both breeding and non-breeding periods, but when both periods are considered, each species appears to use a unique niche. However, analyses of prey item isotope levels, controlled laboratory experiments of species-specific fractionation rates, and better isotopic maps for the region would help improve the interpretation of such isotopic results.

Tropical seabirds have a more limited suite of foraging techniques than do temperate species, as resources tend to be patchier and more limited in the tropical ocean than in temperate regions. Yet, our results confirm and strengthen results from earlier studies (e.g. Spear et al. 2007) that suggest that niche partitioning is similarly prevalent among seabirds in tropical systems as in temperate systems.

Acknowledgements. We thank the National Science Foundation, the National Geographic Society, the Stanford VPUE summer field studies grants, the Stanford Gabilan Graduate Fellowship, the Woods Institute of the Environment, and the Tagging of Pacific Pelagics program for financial or in-kind support. For logistical and material support, we thank the US Fish and Wildlife Service, the Palmyra Atoll National Wildlife Refuge, The Nature Conservancy, and the Palmyra Atoll Research Consortium. For genetic analysis of sex, we thank F. Hailer and E. A. Schreiber at the Smithsonian Institute. For assistance in the field and laboratory, we thank D. Mucciarone, K. Pollock, J. Svendson, S. Barclay, C. Depkin, A. Briggs, M. deGraff, C. Burniske, and L. Palumbi.

\section{LITERATURE CITED}

Ainley DG, Ribic CA, Fraser WR (1992) Does prey preference affect habitat choice in Antarctic seabirds? Mar Ecol Prog Ser 90:207-221

Ainley DG, Ribic CA, Fraser WR (1994) Ecological structure among migrant and resident seabirds of the ScotiaWeddell confluence region. J Anim Ecol 63:347-364 Ashmole NP (1968) Body size, prey size, and ecological segre- 
gation in five sympatric tropical terns (Aves: Laridae). Syst Zool 17:292-304

Ashmole NP, Ashmole MJ (1967) Comparative feeding ecology of seabirds of a tropical oceanic island. Peabody Mus Nat Hist Yale Univ Bull 24:1-131

> Awkerman JA, Hobson KA, Anderson DJ (2007) Isotopic $\left(\delta^{15} \mathrm{~N}\right.$ and $\delta^{13} \mathrm{C}$ ) evidence for intersexual foraging differences and temporal variation in habitat use in waved albatrosses. Can J Zool 85:273-279

Ballance LT, Pitman RL, Reilly SB (1997) Seabird community structure along a productivity gradient: importance of competition and energetic constraint. Ecology 78: 1502-1518

Bauchinger U, Keil J, McKinney RA, Starck JM, McWilliams SR (2010) Exposure to cold but not exercise increases carbon turnover rates in specific tissues of a passerine. J Exp Biol 213:526-534

Bearhop S, Waldron S, Votier SC, Furness RW (2002) Factors that influence assimilation rates and fractionation of nitrogen and carbon stable isotopes in avian blood and feathers. Physiol Biochem Zool 75:451-458

Bearhop S, Phillips RA, McGill R, Cherel Y, Dawson DA, Croxall JP (2006) Stable isotopes indicate sex-specific and long-term individual foraging specialisation in diving seabirds. Mar Ecol Prog Ser 311:157-164

Becker BH, Newman SH, Inglis S, Beissinger SR (2007) Diet-feather stable isotope $\left(\delta^{15} \mathrm{~N}\right.$ and $\left.\delta^{13} \mathrm{C}\right)$ fractionation in common murres and other seabirds. Condor 109: 451-456

Bertrand A, Bard FX, Josse E (2002) Tuna food habits related to the micronekton distribution in French Polynesia. Mar Biol 140:1023-1037

Catry T, Ramos JA, Le Corre M, Kojadinovic J, Bustamante P (2008) The role of stable isotopes and mercury concentrations to describe seabird foraging ecology in tropical environments. Mar Biol 155:637-647

- Catry T, Ramos JA, Jaquemet S, Faulquier L and others (2009) Comparative foraging ecology of a tropical seabird community of the Seychelles, western Indian Ocean. Mar Ecol Prog Ser 374:259-272

> Cherel Y, Hobson KA (2007) Geographical variation in carbon stable isotope signatures of marine predators: a tool to investigate their foraging areas in the Southern Ocean. Mar Ecol Prog Ser 329:281-287

- Cherel Y, Hobson KA, Weimerskirch H (2000) Using stableisotope analysis of feathers to distinguish moulting and breeding origins of seabirds. Oecologia 122:155-162

Cherel Y, Hobson KA, Hassani S (2005a) Isotopic discrimination between food and blood and feathers of captive penguins: implications for dietary studies in the wild. Physiol Biochem Zool 78:106-115

Cherel Y, Hobson KA, Weimerskirch H (2005b) Using stable isotopes to study resource acquisition and allocation in procellariiform seabirds. Oecologia 145:533-540

> Cherel Y, Le Corre M, Jaquemet S, Ménard F, Richard P, Weimerskirch H (2008) Resource partitioning within a tropical seabird community: new information from stable isotopes. Mar Ecol Prog Ser 366:281-291

Dalerum F, Angerbjörn A (2005) Resolving temporal variation in vertebrate diets using naturally occurring stable isotopes. Oecologia 144:647-658

Fefer S (1987) Trip report to Palmyra Atoll, 16-30 September. Administrative Report. US Fish and Wildlife Service, Honolulu, HI

> Forero MG, Hobson KA, Bortolotti GR, Donázar JA, Bertellotti M, Blanco G (2002) Food resource utilization by the Magellanic penguin evaluated through stable-isotope analysis: segregation by sex and age and influence on offspring quality. Mar Ecol Prog Ser 234:289-299

Graham BS (2009) Trophic dynamics and movements of tuna in the tropical Pacific Ocean inferred from stable isotope analyses. PhD dissertation, University of Hawai'i, Honolulu, HI

Graham BS, Koch PL, Newsome SD, McMahon KW, Aurioles D (2010) Using isoscapes to trace the movement and foraging behaviour of top predators in oceanic ecosystems. In: West JB, Bowen G, Dawson T, Tu K (eds) Isoscapes: understanding movement, pattern, and process on Earth through isotope mapping. Springer, Berlin, p 299-318

Harrison CS, Seki MP (1987) Trophic relationships among tropical seabirds at the Hawaiian Islands. In: Croxall J (ed) Seabirds: feeding ecology and role in marine ecosystems. Cambridge University Press, Cambridge, p 305-326

Harrison CS, Hilda TS, Seki MP (1983) Hawaiian seabird feeding ecology. Wildl Monogr 85:1-71

Hertel F, Ballance LT (1999) Wing ecomorphology of seabirds from Johnston Atoll. Condor 101:549-556

> Hobson KA, Clark RG (1992) Assessing avian diets using stable isotopes. 1. Turnover of ${ }^{13} \mathrm{C}$ in tissues. Condor 94 : 181-188

Hodum PJ, Hobson KA (2000) Trophic relationships among Antarctic fulmarine petrels: insights into dietary overlap and chick provisioning strategies inferred from stableisotope $\left(\delta^{15} \mathrm{~N}\right.$ and $\left.\delta^{13} \mathrm{C}\right)$ analyses. Mar Ecol Prog Ser 198: 273-281

> Jaeger A, Blanchard P, Richard P, Cherel Y (2009) Using carbon and nitrogen isotopic values of body feathers to infer inter- and intra-individual variations of seabird feeding ecology during moult. Mar Biol 156:1233-1240

Jaquemet S, Le Corre M, Marsac F, Potier M, Weimerskirch H (2005) Foraging habitats of the seabird community of Europa Island (Mozambique Channel). Mar Biol 147: $573-582$

Jaquemet S, Potier M, Cherel Y, Kojadinovic J and others (2008) Comparative foraging ecology and ecological niche of a superabundant tropical seabird: the sooty tern Sterna fuscata in the southwest Indian Ocean. Mar Biol 155: $505-520$

Kelly JF (2000) Stable isotopes of carbon and nitrogen in the study of avian and mammalian trophic ecology. Can J Zool 78:1-27

> Kojadinovic J, Ménard F, Bustamante P, Cosson RP, Le Corre M (2008) Trophic ecology of marine birds and pelagic fishes as determined by stable isotope analysis. Mar Ecol Prog Ser 361:239-251

Longhurst AR, Pauly D (1987) Ecology of tropical oceans. Academic Press, San Diego, CA

Phillips RA, Bearhop S, McGill RAR, Dawson DA (2009) Stable isotopes reveal individual variation in migration strategies and habitat preferences in a suite of seabirds during the nonbreeding period. Oecologia 160:795-806

Post DM, Layman CA, Arrington DA, Takimoto G, Quattrochi J, Montaňa CG (2007) Getting to the fat of the matter: models, methods and assumptions for dealing with lipids in stable isotope analyses. Oecologia 152:179-189

Roth JD, Hobson KA (2000) Stable carbon and nitrogen isotopic fractionation between diet and tissue of captive red fox: implications for dietary reconstruction. Can J Zool 78:848-852

Schreiber RW, Hensley DA (1976) Diets of Sula dactylatra, Sula sula, and Fregata minor on Christmas Island, Pacific Ocean. Pac Sci 30:241-248

Seki MP, Harrison CS (1989) Feeding ecology of two subtropical seabird species at French Frigate Shoals, Hawaii. Bull 
Mar Sci 45:52-67

Shaffer SA (2010) A review of seabird energetics using the doubly labeled water method. Comp Biochem Physiol A Mol Integr Physiol doi:10.1016/j.cbpa.2010. 07.012

Shaffer SA, Costa DP, Weimerskirch H (2003) Foraging effort in relation to time constraints of reproduction in free-ranging albatrosses. Funct Ecol 17:66-74

Shchetinnikov AS (1992) Feeding spectrum of squid Sthenoteuthis oualaniensis (Oegopsida) in the Eastern Pacific. J Mar Biol Assoc UK 72:849-860

Spear LB, Ainley DG (1997) Flight behaviour of seabirds in relation to wind direction and wing morphology. Ibis 139: 221-233

Spear LB, Ainley DG, Walker WA (2007) Foraging dynamics of seabirds in the eastern tropical Pacific Ocean. Cooper Ornithological Society, Los Angeles, CA

Stevenson C, Katz LS, Micheli F, Block B and others (2007) High apex predator biomass on remote Pacific Islands. Coral Reefs 26:47-51

Surman CA, Wooller RD (2003) Comparative foraging ecology of five sympatric terns at a sub-tropical island in the eastern Indian Ocean. J Zool 259:219-230

Thompson DR, Phillips RA, Stewart FM, Waldron S (2000) Low $\delta^{13} \mathrm{C}$ signatures in pelagic seabirds: lipid ingestion as a potential source of ${ }^{13} \mathrm{C}$-depleted carbon in the Procellariformes. Mar Ecol Prog Ser 208:265-271

Vanderklift MA, Ponsard S (2003) Sources of variation in con-

Editorial responsibility: Yves Cherel,

Villiers-en-Bois, France sumer-diet $\delta^{15} \mathrm{~N}$ enrichment: a meta-analysis. Oecologia 136:169-182

Weimerskirch H, Le Corre M, Jaquemet S, Potier M, Marsac F (2004) Foraging strategy of a top predator in tropical waters: great frigatebirds in the Mozambique Channel. Mar Ecol Prog Ser 275:297-308

- Weimerskirch H, Le Corre M, Jaquemet S, Marsac F (2005) Foraging strategy of a tropical seabird, the red-footed booby, in a dynamic marine environment. Mar Ecol Prog Ser 288:251-261

- Weimerskirch H, Le Corre M, Ropert-Coudert Y, Kato A, Marsac F (2006) Sex-specific foraging behaviour in a seabird with reversed sexual dimorphism: the red-footed booby. Oecologia 146:681-691

Weimerskirch H, Le Corre M, Gadenne H, Pinaud D, Kato A, Ropert-Coudert Y, Bost CA (2009a) Relationship between reversed sexual dimorphism, breeding investment and foraging ecology in a pelagic seabird, the masked booby. Oecologia 161:637-649

> Weimerskirch H, Shaffer SA, Tremblay Y, Costa DP and others (2009b) Species- and sex-specific differences in foraging behaviour and foraging zones in blue-footed and brown boobies in the Gulf of California. Mar Ecol Prog Ser 391: 267-278

Young HS, Shaffer SA, McCauley DJ, Foley DG, Dirzo R, Block BA (2010) Resource partitioning by species but not sex in sympatric boobies in the central Pacific Ocean. Mar Ecol Prog Ser 403:291-301

Submitted: May 3, 2010; Accepted: August 2, 2010

Proofs received from author(s): September 23, 2010 